\title{
Streblidae (Diptera) on bats (Chiroptera) in an area of Atlantic Forest, state of Rio de Janeiro
}

\author{
Streblidae (Diptera) em morcegos (Chiroptera) numa área de Floresta Atlântica, Estado do Rio de Janeiro \\ Elizabete Captivo Lourenço ${ }^{1 *}$; Priscilla Maria Peixoto Patrício'; Michele da Costa Pinheiro루 \\ Renan Medeiros Dias ${ }^{1}$; Kátia Maria Famadas ${ }^{1}$
}

${ }^{1}$ Laboratório de Artrópodes Parasitas, Departamento de Parasitologia Animal, Instituto de Veterinária, Universidade Federal Rural do Rio de Janeiro - UFRRJ, Seropédica, RJ, Brasil

Received November 19, 2013

Accepted February 26, 2014

\begin{abstract}
Because of the few records of Streblidae on bats, despite extensive study on these mammals in the state of Rio de Janeiro, a survey was carried out in an area of Atlantic Forest, in the municipality of Nova Iguaçu, known as the Tinguá region. Thirteen species were added to the list of Streblidae in the state of Rio de Janeiro, of which two were new records for Brazil. Thirty-one species have now been reported this state.
\end{abstract}

Keywords: Bat flies, ectoparasites, new reports, Phyllostomidae, Tinguá Biological Reserve.

\section{Resumo}

Devido aos poucos registros de Streblidae em morcegos, apesar do amplo estudo com esses mamíferos no Estado do Rio de Janeiro, foi realizado um levantamento numa área de Floresta Atlântica, no Município de Nova Iguaçu, conhecida como regiâo do Tinguá. Foram adicionadas 13 espécies na lista de Streblidae do Estado do Rio de Janeiro, sendo dois novos registros para o Brasil, totalizando 31 espécies relatadas para o estado.

Palavras-chave: Moscas de morcegos, ectoparasitos, novos registros, Phyllostomidae, Reserva Biológica do Tinguá.

\section{Introduction}

Although the bat fauna of the state of Rio de Janeiro has been widely studied, this is not true for their ectoparasites. Streblidae is one of the better studied bat ectoparasite taxa in Brazil and, until now, only sixteen species had been recorded in this state (MIRANDA-RIBEIRO, 1907; LIMA, 1921; JOBLING, 1939; WENZEL et al., 1966; WENZEL, 1970; ESBÉRARD; BERGALLO, 2004; ESBÉRARD; FARIA, 2006; LOURENÇO; ESBÉRARD, 2011; ALMEIDA et al., 2011).

One of the main remaining areas of Atlantic Forest in the state of Rio de Janeiro is the Tinguá Biological Reserve. Although this reserve harbors several species of bats (DIAS; PERACCHI, 2008), there is no information about bat flies. This paper provides an update on the number of Streblidae in the state of Rio de Janeiro, Brazil, with reports on bat flies in the Tinguá region.

\section{Methodology}

One area in the Tinguá Biological Reserve (22 $34^{\prime} 57.4^{\prime \prime}$ S; $\left.043^{\circ} 26^{\prime} 15.9^{\prime \prime} \mathrm{W}\right)$ and two areas surrounding it (22 $35^{\prime} 16.53^{\prime \prime}$

*Corresponding author: Elizabete Captivo Lourenço

Laboratório de Artrópodes Parasitas, Departamento de Parasitologia

Animal, Instituto de Veterinária, Universidade Federal Rural do Rio de

Janeiro - UFRRJ, Rod. BR 465, km 7, CEP 23890-000, Seropédica, RJ, Brasil

e-mail: beteclouren1205@yahoo.com.br
S; $043^{\circ} 24^{\prime} 13.86^{\prime \prime} \mathrm{W}$ and $22^{\circ} 36^{\prime} 50.69^{\prime \prime}$ S; $\left.043^{\circ} 24^{\prime} 47.17^{\prime \prime} \mathrm{W}\right)$ were sampled for bats. All of these areas are located in the far northeast of the municipality of Nova Iguaçu, state of Rio de Janeiro. The bats were captured using mist nets $(12 \times 3 \mathrm{~m}$ and mesh of $20 \mathrm{~mm}$ ) between May 2011 and April 2012, over a total of 36 sampling nights. Flies on the bats were removed with the aid of forceps and were stored in microtubes containing $70 \%$ ethanol. The samples were collected under license from SISBIO/ ICMBio, under number 28064-2. The bats were identified based on Gardner (2007) and Dias and Peracchi (2008). The bat flies were identified with the aid of a stereoscopic microscope, using dichotomous keys and descriptions (WENZEL et al., 1966; WENZEL, 1976; GUERRERO, 1994, 1995, 1996, 1998; GRACIOLLI; CARVALHO, 2001; MILLER; TSCHAPKA, 2001). The nomenclature followed Dick and Graciolli (2006) for Streblidae and Gardner (2007) for bats, except for Dermanura which has been elevated to generic status (REDONDO et al., 2008; SOLARI et al., 2009). The vouchers were confirmed by Dr. Gustavo Graciolli and were deposited in the zoological reference collection of the Federal University of Mato Grosso do Sul in the city of Campo Grande, Brazil. Parasite prevalence, mean intensity and mean abundance were determined in accordance with Bush et al. (1997). 


\section{Results and Discussion}

A total of 22 species of Phyllostomidae bats were caught, which were all parasitized by bat flies except for Chiroderma doriae Thomas, 1891, Chiroderma villosum Peters, 1860, Micronycteris hirsuta (Peters, 1869) and Pygoderma bilabiatum (Wagner, 1843). Of 744 captures, 371 (49.83\%) presented 1124 specimens of bat fly, belonging to 24 species of 9 genera (Table 1).

The most parasitized host was Carollia perspicillata (Linnaeus, 1758), with seven species of bat flies, and the bat flies found in the greatest numbers of hosts were Aspidoptera phyllostomatis (Perty, 1833) and Paratrichobius longicrus (Miranda-Ribeiro, 1907), in five hosts each. The most abundant species was Trichobius joblingi Wenzel, 1966 ( $\mathrm{n}=241$ ), which was found to mainly parasitize its primary host, C. perspicillata (97.1\%), which was also one of the most commonly caught species $(\mathrm{n}=187)$, thus showing that this fly had high prevalence $(51.87 \%)$. Thirteen new species were added to the records for the state of Rio de Janeiro, and two of them were new records for Brazil (Table 2). There was also one new species of Strebla (determined by Dr. Graciolli), which was

Table 1. Species of Streblidae on bats captured in the Atlantic Forest, Tinguá region, municipality of Nova Iguaçu, Rio de Janeiro, between May 2011 and April 2012. NF: number of bat flies; IH: number of infested host individuals; P: prevalence (\%); MI: mean intensity of infestation; MA: mean abundance.

\begin{tabular}{|c|c|c|c|c|c|}
\hline Taxa & NF & IH & $\mathbf{P}$ & MI & MA \\
\hline \multicolumn{6}{|l|}{ Anastrebla caudiferae Wenzel, 1976} \\
\hline Anoura caudifer (É. Geoffroy, 1818) & 1 & 1 & 14.29 & 1.00 & 0.143 \\
\hline \multicolumn{6}{|l|}{ Anastrebla modestini Wenzel, 1966} \\
\hline Lonchophylla peracchii Dias et al., 2013 & 1 & 1 & 100.00 & 1.00 & 1.000 \\
\hline \multicolumn{6}{|l|}{ Aspidoptera falcata Wenzel, 1976} \\
\hline Artibeus fimbriatus Gray, 1838 & 3 & 3 & 5.17 & 1.00 & 0.052 \\
\hline Artibeus planirostris (Spix, 1823) & 2 & 2 & 8.70 & 1.00 & 0.087 \\
\hline Carollia perspicillata (Linnaeus, 1758) & 13 & 4 & 2.14 & 3.25 & 0.070 \\
\hline Sturnira lilium (É. Geoffroy, 1810) & 176 & 51 & 36.17 & 3.45 & 1.248 \\
\hline \multicolumn{6}{|l|}{ Aspidoptera phyllostomatis (Perty, 1833) } \\
\hline A. fimbriatus & 27 & 17 & 29.31 & 1.59 & 0.466 \\
\hline Artibeus lituratus (Olfers, 1818) & 3 & 2 & 0.97 & 1.50 & 0.015 \\
\hline Artibeus obscurus (Schinz, 1821) & 2 & 2 & 5.88 & 1.00 & 0.059 \\
\hline A. planirostris & 8 & 4 & 17.39 & 2.00 & 0.348 \\
\hline S. lilium & 1 & 1 & 0.71 & 1.00 & 0.007 \\
\hline \multicolumn{6}{|l|}{ Megistopoda aranea (Coquillett, 1899) } \\
\hline A. fimbriatus & 28 & 17 & 29.31 & 1.65 & 0.483 \\
\hline A. lituratus & 1 & 1 & 0.49 & 1.00 & 0.005 \\
\hline A. obscurus & 3 & 1 & 2.94 & 3.00 & 0.088 \\
\hline A. planirostris & 6 & 5 & 21.74 & 1.20 & 0.261 \\
\hline \multicolumn{6}{|l|}{ Megistopoda proxima (Séguy, 1926) } \\
\hline A. lituratus & 1 & 1 & 0.49 & 1.00 & 0.005 \\
\hline C. perspicillata & 16 & 4 & 2.14 & 4.00 & 0.086 \\
\hline Platyrrhinus lineatus (É. Geoffroy, 1810) & 1 & 1 & 14.29 & 1.00 & 0.143 \\
\hline S. lilium & 129 & 63 & 44.68 & 2.05 & 0.915 \\
\hline \multicolumn{6}{|l|}{ Metelasmus pseudopterus Coquillet, 1907} \\
\hline A. fimbriatus & 3 & 3 & 5.17 & 1.00 & 0.052 \\
\hline A. lituratus & 1 & 1 & 0.49 & 1.00 & 0.005 \\
\hline \multicolumn{6}{|l|}{ Neotrichobius delicatus Machado-Allison, 1966} \\
\hline Dermanura cinerea (Gervais, 1855) & 1 & 1 & 33.33 & 1.00 & 0.333 \\
\hline Vampyressa pusilla (Wagner, 1843) & 2 & 2 & 100.00 & 1.00 & 1.000 \\
\hline \multicolumn{6}{|l|}{ Paraeuctenodes similis Wenzel, 1976} \\
\hline C. perspicillata & 27 & 22 & 11.76 & 1.23 & 0.144 \\
\hline \multicolumn{6}{|l|}{ Paratrichobius longicrus (Miranda Ribeiro, 1907) } \\
\hline A. fimbriatus & 1 & 1 & 1.72 & 1.00 & 0.017 \\
\hline A. lituratus & 147 & 74 & 36.00 & 1.99 & 0.714 \\
\hline A. planirostris & 3 & 1 & 4.35 & 3.00 & 0.130 \\
\hline C. perspicillata & 2 & 2 & 1.07 & 1.00 & 0.011 \\
\hline Platyrrhinus recifinus (Thomas, 1901) & 1 & 1 & 4.35 & 1.00 & 0.043 \\
\hline
\end{tabular}

${ }^{1}$ Damaged material that did not allow identification of the lowest taxonomic level. 
Table 1. Continuation...

\begin{tabular}{|c|c|c|c|c|c|}
\hline Taxa & NF & IH & $\mathbf{P}$ & MI & MA \\
\hline \multicolumn{6}{|l|}{ Strebla diphyllae Wenzel, 1966} \\
\hline Diphylla ecaudata Spix, 1823 & 2 & 2 & 66.67 & 1.00 & 0.667 \\
\hline \multicolumn{6}{|l|}{ Strebla guajiro (García \& Casal, 1965) } \\
\hline A. caudifer & 3 & 2 & 28.57 & 1.50 & 0.429 \\
\hline C. perspicillata & 94 & 54 & 28.88 & 1.74 & 0.503 \\
\hline S. lilium & 1 & 1 & 0.71 & 1.00 & 0.007 \\
\hline \multicolumn{6}{|l|}{ Strebla machadoi Wenzel ,1966 } \\
\hline Micronycteris minuta (Gervais, 1856) & 5 & 1 & 100.00 & 5.00 & 5.000 \\
\hline \multicolumn{6}{|l|}{ Strebla wiedemanni Kolenati, 1856} \\
\hline Desmodus rotundus (É. Geoffroy, 1810) & 28 & 13 & 43.33 & 2.15 & 0.933 \\
\hline \multicolumn{6}{|l|}{ Strebla sp. nov. } \\
\hline L. peracchii & 1 & 1 & 100.00 & 1.00 & 1.000 \\
\hline \multicolumn{6}{|l|}{ Trichobius anducei Guerrero, 1998} \\
\hline C. perspicillata & 49 & 30 & 16.04 & 1.63 & 0.262 \\
\hline \multicolumn{6}{|l|}{ Trichobius diphyllae Wenzel, 1966} \\
\hline D. ecaudata & 1 & 1 & 33.33 & 1.00 & 0.333 \\
\hline \multicolumn{6}{|l|}{ Trichobius dugesioides dugesioides Wenzel, 1966} \\
\hline Chrotopterus auritus (Peters, 1856) & 1 & 1 & 100.00 & 1.00 & 1.000 \\
\hline S. lilium & 1 & 1 & 0.71 & 1.00 & 0.007 \\
\hline \multicolumn{6}{|l|}{ Trichobius furmani Wenzel, 1966} \\
\hline D. ecaudata & 12 & 2 & 66.67 & 6.00 & 4.000 \\
\hline D. rotundus & 32 & 8 & 26.67 & 4.00 & 1.067 \\
\hline \multicolumn{6}{|l|}{ Trichobius handleyi Wenzel, 1976} \\
\hline M. minuta & 3 & 1 & 100.00 & 3.00 & 3.000 \\
\hline \multicolumn{6}{|l|}{ Trichobius joblingi Wenzel, 1966} \\
\hline C. perspicillata & 234 & 97 & 51.87 & 2.41 & 1.251 \\
\hline S. lilium & 7 & 3 & 2.13 & 2.33 & 0.050 \\
\hline \multicolumn{6}{|l|}{ Trichobius lonchophyllae Wenzel, 1966} \\
\hline Glossophaga soricina (Pallas, 1766) & 3 & 2 & 28.57 & 1.50 & 0.429 \\
\hline L. peracchii & 3 & 1 & 100.00 & 3.00 & 3.000 \\
\hline \multicolumn{6}{|l|}{ Trichobius longipes (Rudow, 1871) } \\
\hline Phyllostomus hastatus (Pallas, 1767) & 11 & 3 & 50.00 & 3.67 & 1.833 \\
\hline \multicolumn{6}{|l|}{ Trichobius tiptoni Wenzel, 1976} \\
\hline A. caudifer & 6 & 4 & 57.14 & 1.50 & 0.857 \\
\hline \multicolumn{6}{|l|}{ Trichobius spp. ${ }^{1}$} \\
\hline A. lituratus & 3 & 2 & 0.97 & 1.50 & 0.015 \\
\hline C. perspicillata & 10 & 9 & 4.81 & 1.11 & 0.053 \\
\hline S. lilium & 4 & 3 & 2.13 & 1.33 & 0.028 \\
\hline Total & 1124 & 371 & 49.86 & 3.03 & 1,58 \\
\hline
\end{tabular}

${ }^{1}$ Damaged material that did not allow identification of the lowest taxonomic level.

found on Lonchophylla peracchii Dias, Esbérard \& Moratelli, 2013. Additional comments have been made for the new occurrences in Brazil and in the state of Rio de Janeiro.

\section{STREBLINAE}

Anastrebla caudiferae Wenzel, 1976

Material examined: 1 female; ex Anoura caudifer (É. Geoffroy, 1818)

Comments: Anoura caudifer is its primary host (WENZEL, 1976), although Bertola et al. (2005) have found it in other hosts. Its occurrences in Brazil were previously restricted to the South (KESSEL, 1925; GRACIOLLI; CARVALHO, 2001; GRACIOLLI; RUI, 2001; RUI; GRACIOLLI, 2005) and, in the Southeast, only the states of São Paulo (BERTOLA et al., 2005) and Minas Gerais (MORAS et al., 2013).

Anastrebla modestini Wenzel, 1966

Material examined: 1 female; ex L. peracchii.

Comments: Its primary host is Anoura geoffroyi Gray, 1838 (WENZEL, 1976; GRACIOLLI; CARVALHO, 2001), with records from the Cerrado and Atlantic Forest for this host and A. caudifer (GRACIOLLI; CARVALHO, 2001; GRACIOLLI; COELHO, 2001; GRACIOLLI; RUI, 2001; BERTOLA et al., 2005; GRACIOLLI et al., 2010; MORAS et al., 2013). This is the first occurrence of this bat fly on species of Lonchophylla Thomas, 
Table 2. Species of Streblidae on bats captured in the Atlantic Forest, Tinguá region, municipality of Nova Iguaçu, Rio de Janeiro, and records for the state.

\begin{tabular}{|c|c|}
\hline $\begin{array}{r}\text { Taxa } \\
\end{array}$ & References \\
\hline Anastrebla caudiferae Wenzel, 1976 & This study \\
\hline Anastrebla modestini Wenzel, 1966 & This study \\
\hline Metelasmus pseudopterus Coquillet, 1907 & This study \\
\hline Paraeuctenodes similis Wenzel, 1976 & This study \\
\hline Strebla alvarezi Wenzel, 1966 & 8 \\
\hline Strebla cristinae Wenzel, 1966 & 7 \\
\hline Strebla diphyllae Wenzel, 1966 & This study \\
\hline Strebla guajiro (García \& Casal, 1965) & This study, 9 \\
\hline Strebla hertigi Wenzel, 1966 & 8 \\
\hline Strebla machadoi Wenzel, 1966 & This study \\
\hline Strebla mirabilis (Waterhouse, 1879) & 6,8 \\
\hline Strebla wiedemanni Kolenati, 1856 & This study, 5 \\
\hline Aspidoptera falcata Wenzel, 1976 & This study \\
\hline Aspidoptera phyllostomatis (Perty, 1833) & This study \\
\hline Mastoptera minuta (Costa Lima, 1921) & 2 \\
\hline Megistopoda aranea (Coquillett, 1899) & This study, 4 \\
\hline Megistopoda proxima (Séguy, 1926) & This study, 4 \\
\hline Neotrichobius delicatus (Machado-Allison, 1966) & This study \\
\hline Noctiliostrebla aitkeni Wenzel, 1966 & 8 \\
\hline Paratrichobius longicrus (Miranda-Ribeiro, 1907) & This study, 1,8 \\
\hline Stizostrebla longirostris Jobling, 1939 & 3 \\
\hline Trichobius lonchophyllae Wenzel, 1966 & This study \\
\hline Trichobius longipes (Rudow, 1871) & This study, 8 \\
\hline Trichobius handleyi Wenzel, 1976 & This study \\
\hline Trichobius joblingi Wenzel, 1966 & This study, 8, 9 \\
\hline Trichobius tiptoni Wenzel, 1976 & This study, 8 \\
\hline Trichobius anducei Guerrero, 1998 & This study \\
\hline Trichobius diphyllae Wenzel, 1966 & This study \\
\hline Trichobius dugesioides Wenzel, 1966 & This study, 6,8 \\
\hline Trichobius furmani Wenzel, 1966 & This study, 8 \\
\hline
\end{tabular}

(1) Miranda-Ribeiro (1907), (2) Lima (1921), (3) Jobling (1939), (4) Wenzel et al. (1966), (5) Wenzel (1970), (6) Esbérard and Bergallo (2004), (7) Esbérard and Faria (2006), (8) Almeida et al. (2011), (9) Lourenço and Esbérard (2011).

1903, in Brazil, though it has been registered on Lonchophylla robusta Miller, 1912, in Costa Rica (MILLER; TSCHAPKA, 2001).

Metelasmus pseudopterus Coquillet, 1907

Material examined: 1 male, 2 females; ex Artibeus fimbriatus Gray, 1838; 1 female; ex Artibeus lituratus (Olfers, 1818).

Comments: In Brazil, it seems to be more associated with A. fimbriatus (GRACIOLLI; CARVALHO, 2001; BERTOLA et al., 2005; ANDERSON; ORTÊNCIO FILHO, 2006), like in the present study, although one individual was found on $A$. lituratus. This relationship was previously reported in Santa Catarina by Wenzel et al. (1966).

Paraeuctenodes similis Wenzel, 1976

Material examined: 19 males, 8 females; ex $C$. perspicillata.

Comments: In Brazil, this was only previously recorded in the Atlantic Forest of the states of Paraná (GRACIOLLI; CARVALHO, 2001) and São Paulo (BERTOLA et al., 2005), on its primary host.

Strebla diphyllae Wenzel, 1966

Material examined: 2 females; ex Diphylla ecaudata Spix, 1823.
Comments: In Brazil, there were two previous recorded of this species: one to the North (WENZEL, 1976) and another to the South (PREVEDELLO et al., 2005). Wenzel et al. (1966) described this species in Guatemala, having also recorded its occurrence in Mexico. Recently, it was reported in Honduras (DICK, 2013).

Strebla machadoi Wenzel, 1966

Material examined: 3 males, 1 female, 1 undetermined; ex Micronycteris minuta (Gervais, 1856).

Comments: Strebla machadoi was previously registered in the state of Pará on Micronycteris megalotis (Gray, 1842) (GUERRERO, 1997). Another few records were reported in Peru (GUERRERO, 1996), Venezuela (WENZEL, 1976; GUERRERO, 1996) and Panama (WENZEL et al., 1966), all on M. minuta.

\section{TRICHOBIINAE}

Aspidoptera falcata Wenzel, 1976

Material examined: 3 females; ex A. fimbriatus; 1 male, 1 female; ex $C$. perspicillata; 8 males, 5 females; ex Sturnira lilium (É. Geoffroy, 1810).

Comments: This bat fly presents widespread distribution including almost all Brazilian biomes (GRACIOLLI; LINARDI, 2002; DIAS et al., 2009; ERIKSSON et al., 2011). Despite being a common species on the lists of bat flies in the Atlantic Forest (AZEVEDO; LINARDI, 2002; BERTOLA et al., 2005; SOARES et al., 2013), it was not previously reported in the study by Almeida et al. (2011) in the state of Rio de Janeiro, mainly due to not catching $S$. lilium, which is its primary host (WENZEL, 1976).

\section{Aspidoptera phyllostomatis (Perty, 1833)}

Material examined: 12 males, 14 females; ex A. fimbriatus; 4 females; ex A. lituratus; 2 females; ex Artibeus obscurus (Schinz, 1821); 1 male, 7 females; ex Artibeus planirostris (Spix, 1823); 1 male; ex $S$. lilium.

Comments: This was recorded on four species of Artibeus Leach, 1821, and the greatest abundance $(\mathrm{n}=27)$ and prevalence (29.31\%) were on A. fimbriatus. Data for the Atlantic Forest are scarce (WENZEL, 1970; GRACIOLLI et al., 2006); however, Graciolli and Carvalho (2001) also recorded this species on the same host. Almeida et al. (2011) did not register this bat fly, despite the high numbers of $A$. lituratus that were caught $(\mathrm{n}=106)$. Likewise, it was not registered by Bertola et al. (2005) on A. lituratus $(\mathrm{n}=102)$ and $A$. fimbriatus $(\mathrm{n}=37)$. Its presence on $S$. lilium, reported by Graciolli et al. (2006), was considered to be accidental. In the Cerrado, it was found on $A$. planirostris (GRACIOLLI et al., 2010; ERIKSSON et al., 2011; SANTOS et al., 2013), and in the Caatinga-Amazon ecotone of the state of Maranhão, on $A$. lituratus and $A$. obscurus (DIAS et al., 2009; SANTOS et al., 2009).

Neotrichobius delicatus Machado-Allison, 1966

Material examined: 1 female; ex Dermanura cinerea (Gervais, 1855); 2 females; ex Vampyressa pusilla (Wagner, 1843).

Comments: This bat fly presents previous records only in Pará (WENZEL, 1970) and the Federal District, on D. cinerea (GRACIOLLI; AGUIAR, 2002). Thus, its presence in the Tinguá region expands its geographical distribution and adds one new biome. The association of $N$. delicatus and $V$. pusilla is the first time that this has been recorded in Brazil. In Bolivia, it was previously found in association with D. cinereus (DICK et al., 2007), in 
Costa Rica with V. pusilla (MILLER; TSCHAPKA, 2001) and in Venezuela with both hosts (WENZEL, 1976).

\section{Trichobius anducei Guerrero, 1998}

Material examined: 28 males, 21 females; ex C. perspicillata.

Comments: Its occurrence in the state of Rio de Janeiro has increased its distribution in the Neotropics, given that previously, it had only been reported in Venezuela (GUERRERO, 1998). While it is very common for its host to be caught (LOURENÇO; ESBÉRARD, 2011), no records had been reported in addition to its description. In the Tinguá region, T. anducei showed high prevalence $(16 \%)$ and abundance $(n=49)$, and was the third most abundant bat fly on $C$. perspicillata.

Trichobius diphyllae Wenzel, 1966

Material examined: 1 female; ex D. ecaudata.

Comments: This is the first record in Brazil. Previously, occurrences in Guatemala, Mexico, Venezuela and Peru on the same host have been reported (WENZEL et al., 1966; WENZEL, 1970; GUERRERO, 1995).

Trichobius handleyi Wenzel, 1976

Material examined: 3 males; ex $M$. minuta.

Comments: This is the first record in Brazil. There have previously been records in Costa Rica parasitizing Lophostoma brasiliense Peters, 1867, and Lophostoma silvicolum d'Orbigny, 1836 (MILLER; TSCHAPKA, 2001); in Venezuela on G. soricina, Phyllostomus elongatus (É. Geoffroy, 1810) and M. hirsuta; and in Peru on M. minuta and M. megalotis (WENZEL, 1976; GUERRERO, 1995).

\section{Trichobius lonchophyllae Wenzel, 1966}

Material examined: 2 males, 1 female; ex Glossophaga soricina (Pallas, 1766); 3 females; ex L. peracchii.

Comments: There have previously been records on Lonchophylla dekeyseri Taddei, Vizotto \& Sazima, 1983, in the Federal District, in the Cerrado (GRACIOLLI; COELHO, 2001; GRACIOLLI; AGUIAR, 2002) and on G. soricina in the state of Minas Gerais, in the Atlantic Forest (AZEVEDO; LINARDI, 2002). Lonchophylla peracchii is a new host of $T$. lonchophyllae. Other records of this parasite were made in Costa Rica (TIMM et al., 1989; MILLER; TSCHAPKA, 2001), Venezuela (WENZEL, 1976), Colombia (MARINKELLE; GROSE, 1981) and Panama (WENZEL et al., 1966), on L. robusta.

Some streblids, such as Megistopoda Macquart, 1852, and Aspidoptera Coquillett, 1899, were expected to occur in the state of Rio de Janeiro because of their association with hosts already listed for this state and for the Atlantic Forest, such as Artibeus and Sturnira Gray, 1842 (KOMENO; LINHARES, 1999; AZEVEDO; LINARDI, 2002; BERTOLA et al., 2005; GRACIOLLI et al., 2006). Other species cited here have seldom been reported in Brazil, probably due to the low numbers of their hosts that have been caught, such as the bat flies found on M. minuta, L. peracchii, $V$. pusilla and D. ecaudata. In contrast, the presence of T. anducei on $C$. perspicillata, which is a new report for Brazil, shows that little is known about the relationships of these bat flies with bats. It is noteworthy that $C$. perspicillata is one of the most commonly caught bats and also one of the most parasitized (LOURENÇO; ESBÉRARD, 2011). Through this study it was possible expand the geographical distribution of Streblidae, thereby contributing to the state list, which now contains 31 species.

\section{Acknowledgements}

To Tinguá Biological Reserve, Entidade Ambientalista Onda Verde, Sindipetro Caxias and FAPERJ (E-26/111.364/2011), CNPq, Capes. To Dr. Gustavo Graciolli for confirmation of vouchers.

\section{References}

Almeida JC, Silva SSP, Serra-Freire NM, Valim MP. Ectoparasites (Insecta and Acari) associated with bats in Southeastern Brazil. J Med Entomol 2011; 48(4): 753-757. http://dx.doi.org/10.1603/ME09133

Anderson R, Ortêncio Filho H. Dípteros ectoparasitas (Diptera, Streblidae) de filostomídeos (Chiroptera, Mammalia) do Parque Municipal no Cinturão Verde de Cianorte, Paraná, Brasil e sua incidência ao longo das estaçôes do ano. Chiroptera Neotrop 2006; 12(1): 238-243.

Azevedo AA, Linardi PM. Streblidae (Diptera) of phyllostomid bats from Minas Gerais, Brazil. Mem Inst Oswaldo Cruz 2002; 97(3): 421-422. http://dx.doi.org/10.1590/S0074-02762002000300026

Bertola, PB, Aires CC, Favorito SE, Graciolli G, Amaku M, Rocha MP. Bat flies (Diptera: Streblidae, Nycteribiidae) parasitic on bats (Mammalia: Chiroptera) at Parque Estadual da Cantareira, São Paulo, Brazil: parasitism rates and host-parasite associations. Mem Inst Oswaldo Cruz 2005; 100(1): 25-32. http://dx.doi.org/10.1590/S007402762005000100005

Bush AO, Lafferty KD, Lotz JM, Shostak AW. Parasitology meets ecology on its own terms: Margolis et al. revisited. J Parasitol 1997; 83(4): 575-583. PMid:9267395. http://dx.doi.org/10.2307/3284227

Dias D, Peracchi AL. Quirópteros da Reserva Biológica do Tinguá, Estado do Rio de Janeiro, sudeste do Brasil (Mammalia: Chiroptera). Rev Bras Zool 2008; 25(2): 333-369. http://dx.doi.org/10.1590/S010181752008000200023

Dias PA, Santos CLC, Rodrigues FS, Rosa LC, Lobato KS, Rebelo JMM. Espécies de moscas ectoparasitas (Diptera, Hippoboscoidea) de morcegos (Mammalia, Chiroptera) no estado do Maranhão. Rev Bras Entomol 2009; 53(1): 128-133. http://dx.doi.org/10.1590/S008556262009000100027

Dick CW, Graciolli G. Checklist of world Streblidae (Diptera: Hippoboscoidea) [online]. Nat Scie Foundation; 2006. 7 p. [cited 2013 Jan 10]. Available from: http://fm1.fieldmuseum.org/aa/Files/cdick/ Streblidae_Checklist_2oct06.pdf.

Dick CW, Gettinger D, Gardner SL. Bolivian ectoparasites: A survey of bats (Mammalia: Chiroptera). Comp Parasitol 2007; 74(2): 372-377. http://dx.doi.org/10.1654/4264.1

Dick CW. Review of the bat flies of Honduras, Central America (Diptera: Streblidae). J Parasitol Res 2013; 2013: ID 437696. http://dx.doi. org/10.1155/2013/437696

Eriksson A, Graciolli G, Fischer E. Bat flies on phyllostomid hosts in the Cerrado region: component community, prevalence and intensity of parasitism. Mem Inst Oswaldo Cruz 2011; 106(3): 274-278. http:// dx.doi.org/10.1590/S0074-02762011000300004

Esbérard CEL, Bergallo HG. Aspectos sobre a biologia de Tonatia bidens (Spix) no Estado do Rio de Janeiro, sudeste do Brasil (Mammalia, Chiroptera, Phyllostomidae). Rev Bras Zool 2004; 21(2): 253-259. http:// dx.doi.org/10.1590/S0101-81752004000200014 
Esbérard CEL, Faria D. New records of Phylloderma stenops Peters, 1865 in the Atlantic Forest, Brazil (Chiroptera, Phyllostomidae). Biota Neotrop 2006; 6(2): 1-5.

Gardner AL. Order Chiroptera Blumenbach, 1779. In: Gardner AL, editor. Mammals of South America, vol. 1: marsupials, xenarthrans, shrews, and bats. Chicago: The University of Chicago press; 2007. p. 187-484.

Graciolli G, Carvalho CJB. Moscas ectoparasitas (Diptera: Hippoboscoidea) de morcegos (Mammalia: Chiroptera) do estado do Paraná. II. Streblidae. Chave pictórica para gêneros e espécies. Rev Bras Zool 2001; 18(3): 907-960. http://dx.doi.org/10.1590/S010181752001000300026

Graciolli G, Coelho DC. Streblidae (Diptera, Hippoboscoidea) sobre morcegos filostomídeos (Chiroptera, Phyllostomidae) em cavernas do Distrito Federal, Brasil. Rev Bras Zool 2001; 18(3): 965-970. http:// dx.doi.org/10.1590/S0101-81752001000300028

Graciolli G, Rui AM. Streblidae (Diptera, Hippoboscoidea) em morcegos (Chiroptera, Phyllostomidae) no nordeste do Rio Grande do Sul, Brasil. Iheringia Sér Zool 2001; (90): 85-92. http://dx.doi.org/10.1590/S007347212001000100009

Graciolli G, Linardi PM. Some Streblidae and Nycteribiidae (Diptera: Hippoboscoidea) from Maracá Island, Roraima, Brazil. Mem Inst Oswaldo Cruz 2002; 97(1): 139-141. PMid:11992166. http://dx.doi. org/10.1590/S0074-02762002000100026

Graciolli G, Aguiar LS. Ocorrência de moscas ectoparasitas (Diptera, Streblidae e Nycteribiidae) de morcegos (Mammalia, Chiroptera) no Cerrado de Brasília, Distrito Federal, Brasil. Rev Bras Zool 2002; 19(S1): 177-181. http://dx.doi.org/10.1590/S010181752002000500012

Graciolli G, Cáceres NC, Bornschein MR. Novos registros de moscas ectoparasitas (Diptera, Streblidae e Nycteribiidae) de morcegos (Mammalia, Chiroptera) em áreas de transição cerrado-floresta estacional no Mato Grosso do Sul, Brasil. Biota Neotrop 2006; 6(2): 1-4. http:// dx.doi.org/10.1590/S1676-06032006000200028

Graciolli G, Zortea M, Carvalho LFAC. Bat flies (Diptera, Streblidae and Nycteribiidae) in a Cerrado area of Goiás State, Brazil. Rev Bras Entomol 2010; 54(3): 511-514. http://dx.doi.org/10.1590/S008556262010000300025

Guerrero R. Catálogo de los Streblidae (Diptera: Pupípara) parasitos de murciélagos (Mammalia: Chiroptera) del nuevo mundo II. Los grupos: pallidus, caecus, major, uniformis y longipes del género Trichobius Gervalis, 1844. Acta Biol Venez 1994; 15: 1-18.

Guerrero R. Catálogo de los Streblidae (Diptera: Pupípara) parasitos de murciélagos (Mammalia: Chiroptera) del Nuevo Mundo. III. Los grupos: dugesii, dunni y phyllostomae del gênero Trichobius Gervais, 1844. Acta Biol Venez 1995; 15: 1-27.

Guerrero R. Catálogo de los Streblidae (Diptera: Pupípara) parasitos de murciélagos (Mammalia: Chiroptera) del nuevo mundo VI. Streblinae. Acta Biol Venez 1996; 16: 1-25.

Guerrero R. Catálogo de los Streblidae (Diptera: Pupípara) parasitos de murciélagos (Mammalia: Chiroptera) del nuevo mundo VII. Lista de especies, hospedadores y países. Acta Biol Venez 1997; 17: 9-24.

Guerrero R. Notas sobre batflies (Diptera, Streblidae). I. O gênero Trichobius, com a descrição de duas novas espécies e novas subespécies da Venezuela. Acta Parasitol 1998; 43: 86-93.
Jobling B. A redescription of Pseudostrebla ribeiroi Costa Lima and the description of a new genus and species of the Streblidae from Brazil. Arb Morph Tax Ent Berlin-Dablem 1939; 6(3): 268-275.

Kessel QC. A synopsis of the Streblidae of the world. JVEnt Soc 1925; 33: 11-331.

Komeno CA, Linhares A. Batflies parasitic on some Phyllostomid bats in southeastern Brazil: Parasitism rates and host-parasite Relationships. Mem Inst Oswaldo Cruz 1999; 94(2): 151-156. http://dx.doi.org/10.1590/ S0074-02761999000200004

Lima AC. Sobre os streblideos americanos (Diptera: Pupipara). Arch Esc Sup Agr Med Veter 1921 (5): 17-34.

Lourenço EC, Esbérard CEL. Reinfestation of Streblidae ectoparasites (Diptera) in Carollia perspicillata (Linnaeus, 1758) (Chiroptera). Rev Bras Parasitol Vet 2011; 20(4): 325-330. http://dx.doi.org/10.1590/ S1984-29612011000400012

Marinkelle CJ, Grose ES. A list of ectoparasites of Colombian bats. Rev Biol Trop 1981; 29(1): 11-20. PMid:7339714.

Miller J, Tschapka M. The bat flies of La Selva (Diptera: Nycteribiidae, Streblidae) [online]. Washington: Systematic Entomology Lab; 2001 [cited 2013 Jan 10]. Available from: http://www.biologie.uni-ulm.de/ bio3/Batfly/key.html.

Miranda-Ribeiro A. Alguns dípteros interessantes. Arch Mus Nac 1907; 14: 229-239.

Moras LM, Bernardi LFO, Graciolli G, Gregorin R. Bat flies (Diptera: Streblidae, Nycteribiidae) and mites (Acari) associated with bats (Mammalia: Chiroptera) in a high-altitude region in southern Minas Gerais, Brazil. Acta Parasitol 2013; 58(4): 556-563. http://dx.doi. org/10.2478/s11686-013-0179-x

Prevedello JA, Graciolli G, Carvalho CJB. A fauna de dípteros (Streblidae e Nycteribiidae) ectoparasitos de morcegos (Chiroptera) do estado do Paraná, Brasil: composiçâo, distribuição e áreas prioritárias para novos estudos. Biociências 2005; 13(2): 193-209.

Redondo RAF, Brina LPS, Silva RF, Ditchfield AD, Santos FR. Molecular systematics of the genus Artibeus (Chiroptera: Phyllostomidae). Mol Phylogenet Evol 2008: 49(1): 44-58. http://dx.doi.org/10.1016/j. ympev.2008.07.001

Rui AM, Graciolli G. Moscas ectoparasitas (Diptera, Streblidae) de morcegos (Chiroptera, Phyllostomidae) no sul do Brasil: associações hospedeiros-parasitos e taxas de infestação. Rev Bras Zool 2005; 22(2): 438-445. http://dx.doi.org/10.1590/S010181752005000200021

Santos CLC, Dias PA, Rodrigues FS, Lobato KS, Rosa LC, Oliveira TG, et al. Moscas ectoparasitas (Diptera: Streblidae) de morcegos (Mammalia: Chiroptera) do Município de Sáo Luís, MA: Taxas de infestação e associaçóes parasito-hospedeiro. Neotrop Entomol 2009; 38(5): 595-601. PMid:19943006. http://dx.doi. org/10.1590/S1519-566X2009000500006

Santos CLC, Pereira ACN, Bastos VJC, Graciolli G, Rebêlo JMM. Parasitism of ectoparasitic flies on bats in the northern Brazilian cerrado. Acta Parasitol2013; 58(2): 207-214. http://dx.doi.org/10.2478/s11686013-0135-9

Soares FAM, Graciolli G, Alcântara DMC, Ribeiro CEBP, Valença GC, Ferrari SF. Bat flies (Diptera: Streblidae) ectoparasites of bats at an Atlantic Rainforest site in northeastern Brazil. Biota Neotrop 2013; 13(2): 242246. http://dx.doi.org/10.1590/S1676-06032013000200024 
Solari S, Hoofer SR, Larsen PA, Brown AD, Bull RJ, Guerrero JA, et al. Operational criteria for genetically defined species: analysis of the diversification of the small fruit-eating bats, Dermanura (Phyllostomidae: Stenodermatinae). Acta Chiropterol 2009; 11(2): 279-288. http://dx.doi. org/10.3161/150811009X485521

Timm RM, Wilson DE, Clausson BL, Laval RK, Vaughan CS. Mammals of La Selva-Braulio Carrillo complex, Costa Rica. North Am faun 1989; 75: 1-162. http://dx.doi.org/10.3996/nafa.75.0001
Wenzel RL, Tipton VJ, Kiewlicz A. The streblid batflies of Panama (Diptera: Calyptera: Streblidae). In: Wenzel RL, Tipton VJ. Ectoparasites of Panama. Chicago: Field Museum of Natural History; 1966. p. 405-675.

Wenzel RL. Family Streblidae. In: Papavero N, editor. A catalogue of the Diptera of the Americas south of the United States 100. São Paulo: Museu de Zoologia Universidade de São Paulo; 1970. 25 p.

Wenzel RL. The Streblidae bat flies of Venezuela (Diptera: Streblidae). Brigham Young Univ sci bull 1976; 20: 1-177. 